\title{
Correction to: Lagrangian mechanics of active systems
}

Anton Solovev and Benjamin M. Friedrich ${ }^{\mathrm{a}}$

TU Dresden, Dresden, Germany

Published online 7 March 2022

(C) The Author(s) 2022

\section{Correction to: \\ Eur Phys J E \\ https://doi.org/10.1140/epje/s10189-021-00016-x}

In Fig. 3D, the hydrodynamic interaction $\Gamma_{12}$ corresponds to a direction angle $\psi=5 \pi / 6$ (instead of $\psi=2 \pi / 3$, as incorrectly written in the figure caption). This does not change any of the conclusion of the paper.

The original article has been corrected.

Open Access This article is licensed under a Creative Commons Attribution 4.0 International License, which permits use, sharing, adaptation, distribution and reproduction in any medium or format, as long as you give appropriate credit to the original author(s) and the source, provide a link to the Creative Commons licence, and indicate if changes were made. The images or other third party material in this article are included in the article's Creative Commons licence, unless indicated otherwise in a credit line to the material. If material is not included in the article's Creative Commons licence and your intended use is not permitted by statutory regulation or exceeds the permitted use, you will need to obtain permission directly from the copyright holder. To view a copy of this licence, visit http://creativecomm ons.org/licenses/by/4.0/.

The original article can be found online at https://doi.org/ 10.1140/epje/s10189-021-00016-x.

\footnotetext{
${ }^{a}$ e-mail: benjamin.m.friedrich@tu-dresden.de (corresponding author)
} 